\title{
The Nexus Between Economic Globalization And Female Labor Force Participation
}

\author{
Azeema Begam \\ \& \\ Nooreen Mujahid \\ Department of Economics \\ University of Karachi
}

\begin{abstract}
Female labor participation is now being considered as one of the main elements of development among policy makers, feminist, sociologists and economists. Female labor supply is an essential factor not only for economic development but also for socio-economic development of a nation. This paper empirically examines the nexus between economic globalization and female labor force participation (FLFP) for Pakistan from 1973 to 2014. Furthermore, this study also explores the role of economic stability through female's unemployment rate, inflation rate and per capita income, and increase in productivity through human capital investment on female labor force. This study also finds out the impact of gender disparity on female labour force participation in Pakistan. For estimation of result, Autoregressive Distributive Lag Model ARDL approach to co-integration has been applied which identifies cointegrating vector(s). After identification of co-integrating vector(s) ARDL model is re-parameterized into ECM. The empirical finding proves a positive and significant relationship between economic globalization and FLFP in long run as well as in short run for Pakistan. Beyond labor laws, policy maker should focus on whether female will get new job opportunities and benefits of new markets especially for females when a country opens it economy. For this purpose, it is necessary to improve access to education for females and developing their skills by providing training program, promote children care centers, legal measures to reduce the burden of domestic chores, and encourage private sector development in different sectors especially in industries that may help to increase employment opportunities for females in Pakistan.
\end{abstract}

Keywords: Economic Globalization, Female Labor Force Participation, Economic Stability, Foreign Direct Investment, Trade Openness.

$$
\begin{aligned}
& \text { ثلخيص }
\end{aligned}
$$

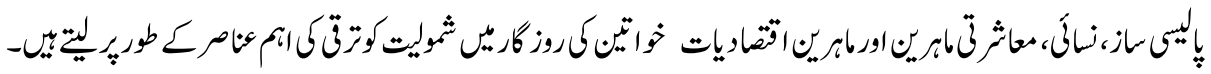

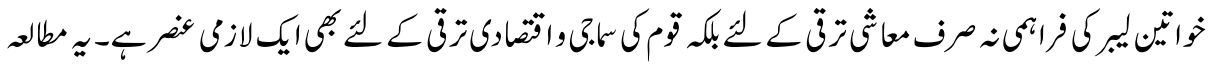

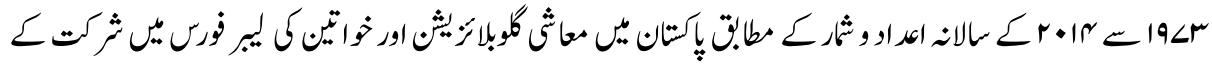

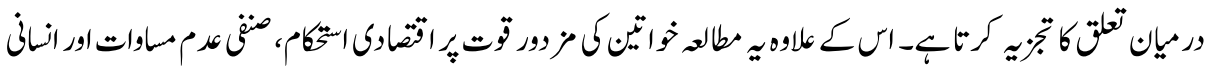

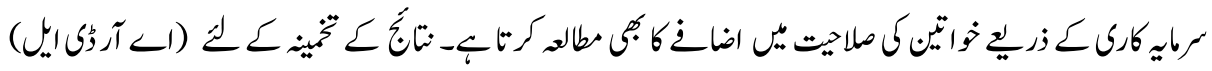




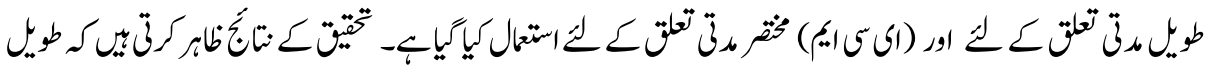

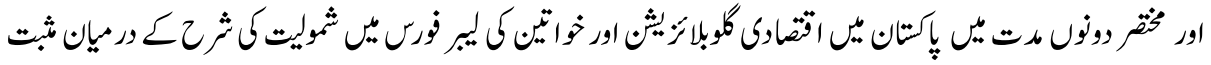

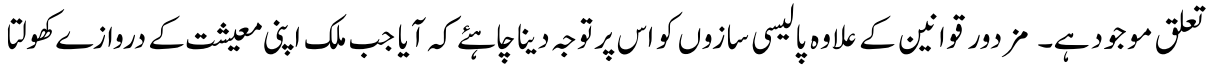

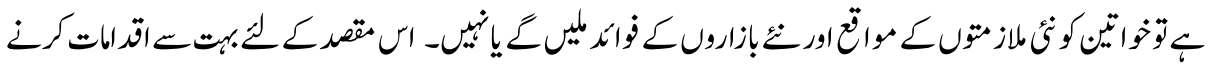

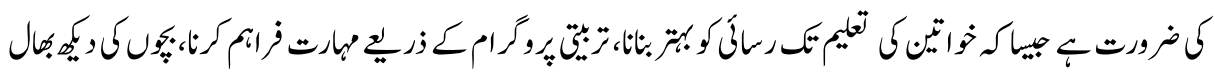

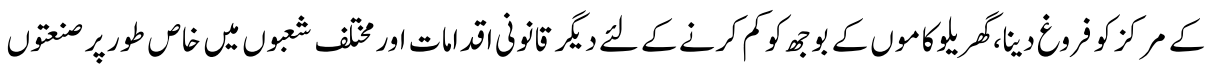

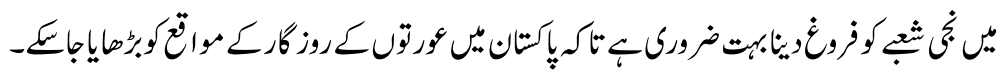

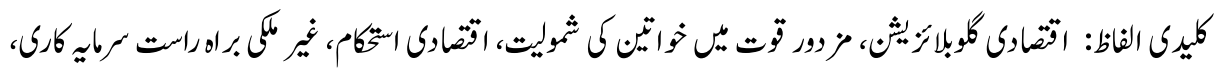

$$
\begin{aligned}
& \text { آزاوانتجارت }
\end{aligned}
$$

\section{Introduction}

Female labor supply is being focused by policy makers, feminist, sociologists, activists and economists. Female labor supply is very essential for not only for economic development but also socio-economic development of a nation. It is also obliging in reducing of poverty ratio. However, due to structural changes and transition process in the economy from agriculture to manufacturing and then service, the demand for female labor is declining in many developing countries (Mujahid, 2013). Nevertheless, increasing participation of female in economic activity will support in reducing gender biasness in every field of life such as in terms of getting facilities in health, education, training and even job opportunities in formal sectors (Esping-Andersen, 2009; Esping-Andersen, Gallie, Hemerijk \& Myers, 2002). As more than $48 \%$ of population, consist of female, who are involved in informal sectors and non-market activities however, female participation in not impressive despite of high economic growth and structural transformation. Female labor also plays the role of a driver for the economic development of the economy.

Due to transition in economy, demand for labor is continuously increasing in the manufacturing sector therefore; many male labors switch over from one sector to another sector. Moreover, females are also entering in labor force that stimulates the industrial growth in response of higher demand for female labor. Furthermore, as economy is developed, the abilities and skills of females improve over time and social constraints that are associated with the conventional mindset change that encourage females to take part in economic activities. The evidence proves that male and female both employments in agriculture sector have declined significantly from $62 \%$ to $14 \%$. Even females are involved in assembly production due to lack of skills, training and opportunities for employments in other industrial sectors (Schultz, 1990). 
Therefore, policy maker must analyze the nature of female labor supply in any particular economy. Eventually, labor force participation by female is considered by both demand and supply. Along with economic benefits, female participation in labor force is an indication of failing unfairness and inequality and improving female empowerment (Mammen \& Paxson, 2000). Moreover feminization or de-feminization of labor force can also be a reaction of depression or increasing uncertainty in labor market thus, female labor supply can maneuver essentially as a protection device for females (Standing, 1989; Balart and Umaña-Aponte, 2010). During the last two decades, emerging and Latin American economies are experiencing a rapid increase of female participation in labor force. More active contribution of female in labor market may uplift the socio-economic position in society. Moreover; high economic growth, narrowing gender inequality, declining fertility rate and technological advancement are major factors that increased female participation in labour market (Galor \& Weil, 1996; Fernandez \& Felício, 2005).

Economic globalization is the a process that increases economic interdependence among different economies at regional and international level through a fast increase in movement of goods and service, financial liberalization and decrease in tariff and nontariff barriers. It is also a process of restructuring and readjustment of domestic and nondomestic resources across globe. Furthermore; structural transition in economy from agriculture to industry and then service sector has reduced female labour force participation in developing countries (Mujahid, 2013). However, increasing female's participation in the economic activities help in reducing gender inequality while providing access to resources. Female participation is also increasing on different sectors which show hidden involvement of females as unpaid family labour. As, $48 \%$ of population is consists of females who are mostly involved in informal sectors and nonmarket activities. Female participation in labour force is not encouraging in Pakistan as compared to other countries of South Asia despite of experiencing structural transformation from agriculture to service sector.

With the development of technology and increasing income level, industrial structures are also experiencing readjustment and upgrading (Shangquan, 2000). In the economic era, trade and foreign investment are playing vital role in order to globalize the entire world. Since, the last two decades, all economies of the world have observed the process of globalization through market openness and economic integration via trade and foreign investment flows (Nissanke \& Thorbecke, 2005). Usually economic globalization has very strong impact on different sectors including labor markets of underdeveloped countries due to insufficient domestic funds. Although there are different aspect of analyzing female labor participation. However, there is a line of few literatures arguing the role of trade and foreign direct investment (FDI) that trade and financial liberalization can increase female participation in labor force in many developing countries. Because there are various interrelated ways through which economic globalization leads to feminizations in labour market (Mujahid, Shabbir \& Shahbaz, 2016). 
Economic globalization refers trade openness, foreign direct and portfolio investment and all structural adjustment policies. Trade liberalization adjusts prices of goods in international and domestics market including wages of labor, inputs composition in production and also income and resources distribution among different economic agents. Trade openness and FDI may also adjust employment and wages of male and females. Although, it depends on the sectors where the demand for labor increases after FDI and trade. Even, foreign investment may also reshape relative wages and employment of different social groups in society and change labor market conditions (Aguayo-Tellez, 2012). The processes of economic globalization have formed new significant ways of analyzing the increasing trend of female's participation in labour force due to trade and financial liberalization which have become crucial elements for growth (Cagatay \& Ozler, 1995; Jokes \& Weston, 1994; Wood, 1991).

There are also some other factors that encourage female labour supply. The splendid growth in manufacturing sectors related to export and export processing zone have improved female's share in non-agriculture labour force among semi-industrialized developing countries in the past (Dolan \& Sorby, 2003). Furthermore, other aspects such as increasing level of education, declining in fertility rate, growth in economy have also significant impacts on FLFP. The new theorists of international division of labour school have introduced gender aspect into the Marxian Theory of Surplus Labour and argue that female can provide a low-cost input from developing countries to developed capitalists countries (Standing,1989). Moreover, there is also relationship exist between female' traditional characteristic and skills with increasing demand for female labour in the small manufacturing industry which leads to enhance trade in developing countries (Elson \& Pearson, 1981).

However; gender specific statistics are very disturbing in Pakistan. Females have no right of ownership privately, to participate in labour market, less access over education and health care, and employment opportunities (Pervaiz, Chani, Jan \& Chaudhary, 2011). By summing up this discussion, we will empirically analyze that how the process of economic integration with world through trade and FDI increase FLFP in Pakistan. The study will also investigate the impact of other factors such as education, fertility rate, gender inequality and economic stability in female labor force participation.

\section{Review of Literature}

Various studies have proved the relationship between economic globalization on female labour force participation. Fatima and Khan (2019) have found impact of globalization on employment share of female in trade-oriented sectors of 21 developing and emerging countries. The finding reveals that global linkage through trade with developed economies can enhance female's employment if developing economies improve skills of 
female labours. Asongu et al.,( 2019) examines the association between globalization and female participation in labour force in 47 Sub-Saharan Africa countries. The finding reveals positive impact of overall globalization index on economic participation of women in Africa.

Oksak \& Koyuncu (2017) examine the impact of globalization on female participation in the labor force with different dimensions such as economic, social, political and overall globalization. While using unbalanced panel data from 1990 to 2015 for 101 countries, the study proves statistically significant relationship between economic, social and overall globalization and FLFP whereas; negative but significant association between FLFP and political globalization. Gaddis \& Pieters (2017), investigate the impact of trade liberalization policies on labour market of Brazil in the 1990s. The result reveals that trade liberalization discourages gender gap between male and female labour force participation and employment rate; however, the effect is larger for male. Therefore, reductions in tariff and non-tariff barriers contribute significantly for the convergence of gender gap in employment and labour force rate. Gender differences are concentrated in tradable sector and low skilled labours however; it pressurizes labour to move from tradable to non-tradable sectors.

Consequently, trade liberalization and increasing male unemployment have also encouraged females to enter in the labour force. While taking data from 1980 to 2010, Mujahid et al., (2016) examine the effects of globalization, female wages, foreign remittance and unemployment on female labour supply. While using ARDL bound testing approach, the result proves long run association among variables. Female wage, foreign remittance and globalization support to increase female labour supply however; unemployment rate has negative effect on labour supply of female. They suggest that informal sectors require more attention and regulations in the era of globalization, because mostly females are employed in informal sectors. Moreover, female entrepreneurship should be encouraged especially in those sectors which are related to females.

Kuete \& Voufo, (2016) empirically investigate increasing level of trade openness and its impact on jobs opportunities and earning for male and female in Cameroon. The data has been taken from national survey of employment and informal sectors that has been conducted on 2005 and 2010. The methodology compares the evolution of trade indicators and female's employment and decomposes the wage gap for identifying the exposure of trade. Three indicators of trade have been used such as import penetration, export intensity and share of trade. The finding of the study shows that trade openness has not provided employment opportunities in exporting sectors where most of the female are employed however it narrowed the gender wage gap. Gupta, (2015) examines the impact of trade liberalization in 1991 on employment share of female in India while using panel data that have been taken from annual survey of industries. although, taste baseddiscrimination theory predict that trade liberalization benefited females however, the 
author found that reduction in tariff and import competition gas reduced female's share in labor force. Larger output tariff increase demand of more skill labors and increase working hours. Therefore, female are prohibited to work long hours by law in India and therefore employment declined.

Maqsood \& Ullah (2014) have investigated the role of globalization on female labor force participation in SAARC countries from the period of 1990 to 2010. For measuring globalization impact, foreign direct investment, trade openness, and urbanization had been used. Panel fixed and panel random effects models have been applied for empirical investigations. The result proved positive and significant impact on urbanization and foreign direct investment in female labor force and negative but significant impact of trade openness on female labor force participation in SAARC countries. Trade openness brought competition in developing countries that require skilled labors. Furthermore, urbanization and FDI have also played significant role in encouraging female's employment in SAAR countries. She suggested that government should create employment opportunities for female and ensure a secure and profitable investment environment in order to attain desired level of economic growth.

Meyer, (2013) examines the effects of economic globalization on occupational inequality and sex segregation. The theory of global economic restructuring and its impact on female work highlights that more economic integration with world brings more opportunities for females in workplace however, it does not remove constraints to female's advancement or improvement in low-paying in unskilled jobs. While taking panel data from 1970 to 1990 for fifty six countries, the finding reveals that global integration reduce occupational inequality and sex segregation. It has been highlighted that global economic restructuring is a gendered process which transform gender inequalities. Yasmin et al., (2013) studied why women do not participate and leave market early in Tehsil Vehari which is a small area of Pakistan. Fro results estimation, random sample of 200 female from rural and urban have been selected through filed survey. The OLS and Logit Model have been applied for analysis. The result indicates that education has positive relation with female participating and earning. Location of female resident shows that women of urban area take more participation as compared to rural women. She suggested that female should achieve at least secondary level education along with technical and specialized knowledge. Ejaz (2011) explored the determinant of female participation in Pakistan and the proved that due to economic development female involvement increased in labor market. Age and marriages factors revealed negative effect on female labor force due to household works however education and income of household have positive association with FLFP. Female participation has been recorded more in agriculture sector as compared to industry or service where females are playing their role in manual labor. Several demographic, social and economic factors determine FLFP for all four provinces. 
Mujhaid \& Zafar (2012) has investigated the role of economic development that encourages female labor force participation in Pakistan from the period of 1980-2010. The finding of the study reveals that encouraging economic policies raise female labor supply in economy and productive activities. The outcome indicates that economic development encourages female labour supply in short and long run periods both. She suggested that government should more concentrate for promoting female labor in formal sectors and informal sectors needs to restructure through encouragement of females. Some feminist scholars like Patel, (1994); Cagatay, Elsoon and Grown, (1995) and Joekes (1995) have also focused also studied the impact of structural adjustment policies (SAPs) for the promotion of export-oriented industries on trade, globalization and employment opportunities of female labor since mid-1980s. Literature reveals that external and internal debts depressed economic growth instead of increase, which further increased the burden of government expenditures and uncertainties in the economy due to policies of governments. Debt also depresses the fiscal and structural reforms due to a huge pressure for repaying to the foreign credits and loans. Binzel \& Assaad (2011) investigate the role of migration of male member of the family to abroad on females decision to increase their participation in labour force both rural and urban areas of Egypt. Through parametric and non-parametric techniques and using cross sectional data of Market Panel Survey 2006, result proves that remittance income decrease working hours of females in urban and rural areas of Egypt. Furthermore, females of rural area are more engaged in non-wage jobs due to international migration. Bhalla \& Kaur, (2011) explore the several aspects that determine female participation in India. They highlight that India has one of the lowest female labour force participation in the world. Females are taking more active part in economic activities in rural areas as compared to urban areas due to poverty. India has also experienced U-shaped relation between female labour force participation and income.

Jadotte (2009) explored the impact of migration and remittances on the outcomes of labor markets by using Haitian Living Conditions Survey of Haiti. He used Zero-altered negative binomial test and Two Stage Least Square (TSLS) method for estimation. The outcome of the study suggested that remittance income has negative impact on labor market for male and female both and reduced their working hours however, the result did not proved the theoretical aspect of female labor that female supply of labor are more sensitive with income remittances. Moghadam (1999) has explained that globalization is a complex phenomenon in this recent year for developed and developing countries both. Economic globalization requires more interaction among countries' in production and trade. After opening of the economics, countries heavily depend on the work of female. As a result of trade expansion, price of imported goods have become competent with domestic price that give pressure to local producers for reducing the cost of factors of production by using cheap labor. 
Plenty of studies of such as Catagay \& Ozler, (1995), Joekes and Weston, (1994) and Standing, (1989) have investigated the role of trade and FDI in employment of females. Export expansion activities are considerably related with feminization of labor in industrial sector. Wood (1991) proved the strong association between feminization of labor in manufacturing sector and export of Sri Lanka, Tunisia, Mauritius, Malaysia and four East Asian countries for the year of 1980-1985. Fontana, Joekes \& Masika, (1998) have explained that women and men achieve different level of advantages from expansion of trade. Furthermore, these benefits which are associated with women are also different with different group and skills of women. Elson (1991) and Palmer (1991) have examined the cost of implication of structural adjustment policies in developing countries. The findings of the study show that macroeconomic and structural adjustment policies are gender neutral that mainly focused on economic growth however, and it impacted more badly on female as compared to male due to distant social and economic role in the society. Structural adjustment policies and macro-economic adjustment are gender bias in developing countries and it tends to advantage men along with an unfriendly social and economic impact on women. There are two different perspective related to trade and gender. On the one hand, trade expansion provides costs and benefits to male and female, however, on the other hand, inference of trade are arbitrated by gender relation with respect to economic, political and social structure of the society. All these perspective related to trade and gender brings diverse effects in different sphere of life for female in term of education, health, labor market for female. It is noticeable that these gender biases in the society influence the policy of trade and outcomes.

\section{Theoretical and Conceptual Framework}

Trade liberalization can affect outcomes of labor market through various channels. The debate on changing labor market outcomes due to trade has been initially analyzed in the traditional theory of trade, such as the Heckscher-Ohlin (HO) theory and StolperSamuelson Theorem. The HO-model suggests static efficiency advantages from trade through specialization on those goods which has comparative advantage then trade it with those goods in which country have comparative disadvantages. It encourages structural changes in production pattern and reallocation of inputs which are abundant factors and used most intensively (Gaddis \& Pieters,2012). The Stolper-Samuelson theory argues that international trade leads to increase real income of the factors that are used extensively in production, while the returns or income of other factors declined (Winters, 1991).

However, a possible reason of restructuring of production and reallocation of resources due to presence of gender elements in labor market. Male and female labour are considered as imperfect substitute as inputs of production (Galor \& Weil, 1996; Sauré \& Zoabi, 2009; Rees \& Riezman, 2012). Similarly, differences in gender perspective in social and cultural comparative inclination have also become a reason of employing females in particular 
sectors (Goldin, 1990). The impact of economic globalization on female have a positive impact that creates job opportunities for both genders particularly for females (Kaur,2018). It encourages different industrial and export zones that requires more domestic labors and foreign direct investment allows more female employments in these areas due to demand of cheap labor force with low wages. Although, it is benefiting to women in terms of jobs accessibility but it deteriorates the position of females in labor markets due to more demand for training, skills and job-related segregation (Seguino, 2006). The theoretical framework shows that female labor force participation may rises due to trade and foreign direct investment which encourages economic activities while creating job opportunities for the females. Foreign firms and organizations bring their investment in host countries through developing more production units. These foreign firms operate under an extremely competitive environment with low level of cost as compared to local firms. Consequently, they maximize their objective by recruiting female labor from developing countries as it is also considered cheap inputs. Because, cheap inputs are an important determinant of FDI therefore, female labour encourages more FDI. Due to gender differences and limited job opportunities, females always prefer low wage jobs in developing countries and hence, upsurge their participation in labor force.

Figure: 1 postulates the association with economic globalization with female participation

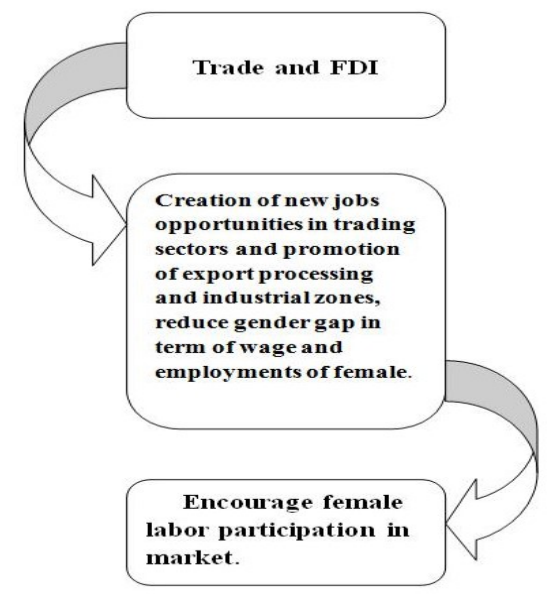

Source: Inspired by Gaddis and Pieters (2012)

In the study of Gaddis and Pieters (2012), it has been proved due to expansion of trade activities and foreign investment new job opportunities have been generated for female that increased supply of female labor supply. The globalization is a multifaceted and exciting phenomenon which requires more incorporation, interaction and collaboration among countries in production, exports and imports. While, the trade and capital liberalization policies have reduced the gender gap in labor force due to structural transformation of the economy from agriculture to manufacturing that encouraged female to take part actively in economic activity (Hayder \& Behrman, 2012). 


\section{Methodology}

\section{Data Source}

The time series data for the period of 1973 to 2014 has been taken from, Global Economy, World Bank indicators, various publication of economic survey of Pakistan, except Composite Gender Inequality Index. Ahmed \& Hyder, (2006) generated composite gender inequality index for Pakistan. This study examines that how economic globalization will help in raising female participation in labor market in Pakistan while taking into account other aspect such as economic stability and gender inequality.

\section{Description of Variables}

This study will explore the nexus between economic globalization and female labor force participation for Pakistan. We have taken trade openness and foreign direct investment as a proxy of economic globalization (Cooray, Gaddis \& Wacker, 2012; Mujahid, 2013; Jaffri, Sana \& Asjed, 2015). Primary and secondary female enrolment ratio and fertility rate (Cooray, Gaddis \& Wacker, 2012; Maqsood \& Ullah, 2014; Jaffri, Sana \& Asjed, 2015; Okşak \& Koyuncu, 2017) are being used to measure the productivity of female because better health and education opportunities increase skill and ability to work and chance to get more employment. Gender Inequity Index measures the inequality in education, health and female labor participation which demonstrates that decline in inequality will help female to take decisions regarding female labor supply. While, per capita income (Mujahid, 2013; Jaffri, Sana \& Asjed, 2015), inflation rate (Mujahid, 2013; Okşak \& Koyuncu, 2017) and female unemployment rate (Mujahid, Shabbir \& Shahbaz, 2016; Tsani et al.,2013) have been taken for measuring impact of macroeconomic factors on female participation in labor force. Economic factors will encourage female to take part in economic activities due to decrease in employment rate or increase in prices due to inflation in the economy.

\section{Modeling Framework}

This study examines the effect of economic globalization for female labor force while taking some other macroeconomic variables. We have taken all data in percentage form except Gender Inequality Index. The general model can be modeled;

FLFP $=$ f( FDI, TOP, GII, PCI , CPI, UNF, FR, ENRL)................(1)

Where,

FLFP = female labor force participation rate

FDI = foreign direct investment

TOP $=$ trade openness 
GII = Gender Inequality Index

PCI = per capita income

$\mathrm{CPI}=$ inflation rate

$\mathrm{UNF}=$ unemployment rate of female

FR = fertility rate

$\mathrm{ENRL}=$ primary and secondary ratio of female

For empirical purpose, all data have been converted into econometrics from while including error term in the model. This error term incorporates impacts of all other relevant variables which have not been taken into model. The econometric form of the model is as followed:

FLFP $_{t}=\alpha_{1}+\alpha_{2}$ FDI $_{t}+\alpha_{3}$ TOP $_{t}+\alpha_{4}$ GII $_{t}+\alpha_{5} \mathrm{PCI}_{\mathrm{t}}+\alpha_{6} \mathrm{CPI}_{\mathrm{t}}+\alpha_{7} \mathrm{UNF}_{\mathrm{t}}+\alpha_{8} \mathrm{FR}_{\mathrm{t}}$ $+\alpha_{9}$ ENRL $_{t}+\varepsilon$ t....... (2)

Where $=\alpha_{1}$ is intercept and, $\alpha_{2}, \alpha_{3}, \alpha_{4}, \alpha_{5}, \alpha_{6}, \alpha_{7}, \alpha_{8}$, and $\alpha_{9}$ are the coefficient of economic globalization, Gender Inequality Index, per capita income, inflation rate , unemployment rate of female, fertility rate and primary and secondary enrolment ratio of female respectively whereas $\varepsilon$ t is residual term.

\section{ARDL Model Estimation}

Numerous empirical researches exist that have used Ordinary Least Square (OLS) method for estimating long run relationship for time series data. However, the assumptions of OLS show that all variables are integrated at level and error term is normally distributed with zero mean and constant variance. Without testing stationary of time series data through various unit root tests, OLS gives vague and spurious results which cannot use for forecasting and future policy analysis.

ARDL stands for Autoregressive Distributive Lag which has gained valuable importance in recent time for time series data analysis. In 1999, Pesaran and Shin introduced ARDL model that further extended by Pesaran, Shin and Smith, (2001). As compared to other traditional techniques and methods of co-integration, ARDL has many benefits due to which this method is preferred. Traditional methods such as Ordinary Least Square and Johansen Co-integration test require that all variables must have same order of integration either I(0) or I(1). However; if variables are not integrated at same order of integration then ARDL is a most appropriate method to estimate model. therefore; ARDL method do not require pre-testing of stationary of data and it can be used with mixture of $\mathrm{I}(0)$ and I(1). ARDL approach to co integration identifies co-integrating vector(s) therefore; each taken variables represent as a single long-run relation equation. Once co-integrating vector is identified, the ARDL model of the co-integrating vector is re-parameterized into error correction model (ECM) for short run relationship (Nkoro \& Uko, 2016). 


\section{Results and Discussion}

Table: 1

Statistical descriptive

\begin{tabular}{|l|c|c|c|c|c|c|c|c|c|}
\hline & FLFP & FDI & TOP & ENRL & FR & GII & UNF & Log(PCI) & CPI \\
\hline Mean & 13.97214 & 14.79452 & 8.896405 & 35.38881 & 5.225714 & 134.8862 & 4.779429 & 2.125815 & 9.576667 \\
\hline Median & 13.55000 & 10.33000 & 7.096112 & 34.28250 & 5.565000 & 135.6500 & 5.000000 & 2.145504 & 8.550000 \\
\hline Maximum & 25.27000 & 45.56000 & 36.48515 & 44.00600 & 6.610000 & 149.1300 & 7.800000 & 3.284664 & 26.70000 \\
\hline Minimum & 6.570000 & 1.030000 & 3.443478 & 25.24900 & 3.120000 & 121.6714 & 2.500000 & 1.064711 & 2.900000 \\
\hline Std. Dev. & 5.636444 & 13.03765 & 6.253565 & 5.770828 & 1.269613 & 8.110281 & 1.617309 & 0.524290 & 5.286018 \\
\hline Scenes & 0.533390 & 1.250965 & 2.589117 & 0.029959 & -0.337964 & -0.005931 & 0.372090 & -0.011512 & 1.442612 \\
\hline Kurtosis & 2.201559 & 3.191470 & 10.70737 & 1.651542 & 1.494148 & 1.801271 & 1.910638 & 2.848098 & 5.116003 \\
\hline Jarque- Bera & 3.107173 & 11.01854 & 150.8809 & 3.188376 & 4.767820 & 2.514912 & 3.045899 & 0.041308 & 22.40347 \\
\hline Probability & 0.211488 & 0.004049 & 0.000000 & 0.203073 & 0.092189 & 0.284377 & 0.218068 & 0.979558 & 0.000014 \\
\hline Sum & 586.8300 & 621.3700 & 373.6490 & 1486.330 & 219.4800 & 5665.221 & 200.7360 & 89.28422 & 402.2200 \\
\hline Dev Sum Sq.. & 1302.550 & 6969.197 & 1603.390 & 1365.401 & 66.08863 & 2696.843 & 107.2433 & 11.27010 & 1145.622 \\
\hline Observations & 42 & 42 & 42 & 42 & 42 & 42 & 42 & 42 & 42 \\
\hline
\end{tabular}

Source: Author estimation

Table 1 shows statistical descriptive of all variables where the mean values of FLFP, FDI, TOP, ENRL, and CPI are more than median values which indicates tendency toward positive skew whereas the mean value of FR, GII, UNF, and LOG(PCI) are less than median value which shows negative skew.

Table: 2

Philips-perrson unit root test

\begin{tabular}{|l|c|c|c|c|}
\hline & \multicolumn{2}{|c|}{$\mathrm{I}(0)$} & \multicolumn{2}{c|}{$\mathrm{I}(1)$} \\
\hline & T-Statistics & Prob- values & T -Statistics & Prob- values \\
\hline FDI & -1.018202 & 0.9302 & -6.377197 & 0.0000 \\
\hline TOP & -5.581057 & 0.0002 & ----- & ----- \\
\hline LOG(PCI) & -2.946193 & 0.1594 & -5.384385 & 0.0004 \\
\hline CPI & -3.259067 & 0.0876 & ----- & ----- \\
\hline ENRL & -3.368598 & 0.0698 & ----- & ----- \\
\hline FLFP & -1.805841 & 0.6836 & -7.972700 & 0.0000 \\
\hline FR & -2.323259 & 0.4126 & 0.489737 & 0.9989 \\
\hline GII & -3.117709 & 0.1158 & -6.803862 & 0.0000 \\
\hline UNF & -2.238806 & 0.4564 & -5.706417 & 0.0002 \\
\hline
\end{tabular}

Source: Author Estimation

Philiphs-Perron(PP) test is also used to check the trends in time series data. Table 2 shows PP test at level and $1^{\text {st }}$ difference with trend and intercepts. The Philiphs Perrson test proved that TOP, CPI and ENRL are integrated at I(0) whereas FDI, PCI, FLFP, GII and UNF are integrated at I(1) with $1 \%, 5 \%$ and $10 \%$ level of significance. However; in PP test except FR is insignificant at level and first difference both. But the results of $\mathrm{ADF}$ proves that $\mathrm{FR}$ is integrated at level. 
Table: 3

ADF unit root test

\begin{tabular}{|l|c|c|c|c|}
\hline & \multicolumn{2}{|c|}{$\mathrm{I}(0)$} & \multicolumn{2}{c|}{$\mathrm{I}(1)$} \\
\hline & T-Statistics & Prob- values & T -Statistics & Prob- values \\
\hline FDI & -1.031102 & 0.9282 & -6.377574 & 0.0000 \\
\hline TOP & -5.579254 & 0.0002 & ----- & ---- \\
\hline LOG(PCI) & -2.872591 & 0.1816 & -6.91986 & 0.0000 \\
\hline CPI & -3.259067 & 0.0876 & ---- & ----- \\
\hline ENRL & -3.183487 & 0.1019 & -6.508042 & 0.0000 \\
\hline FLFP & -2.046113 & 0.5594 & -7.578842 & 0.0000 \\
\hline FR & -3.350411 & 0.0754 & ------ & ------- \\
\hline GII & -3.029136 & 0.1370 & -5.978322 & 0.0001 \\
\hline UNF & -2.238806 & 0.4564 & -5.735576 & 0.0001 \\
\hline
\end{tabular}

Source: Author Estimation

ADF unit roots test is also used to check stationary in time series data. Table 3 describes ADF test at level and $1^{\text {st }}$ difference with trend and intercepts. The ADF test proved that TOP, CPI and FR are integrated at I(0) whereas; FDI, PCI, ENRL, FLFP, GII and UNF are integrated at (1) with $1 \%$ level of significance. Unit root tests provide enough justification to apply ARDL technique for the estimation of results.

For generation estimates, we have applied ARDL approach to co-integration through Microfit 4.0. On the basis of unit root test, it has been proved that main assumption of ARDL has been fulfilled and variables are integrated at level and first difference both. In the first step, we have selected lag length of F-statistic for co-integration which is sensitive to the lag length. After selecting of lag length, we have obtained ARDL model while normalizing FLFP

Table: 4

Autoregressive distributed lag estimates

Estimated Model FLFP $=\mathrm{f}(\mathrm{TOP}$, FDI, ENRL,FR, GII, UNF, PCI, CPI)

Lag length $\quad(2,2,2,0,2,1,2,2,1)$ based on AIC

Dependent variable is FLFP

\begin{tabular}{|l|c|c|c|}
\hline Regressor & Coefficient & $\begin{array}{l}\text { Standard } \\
\text { Error }\end{array}$ & T-Ratio[Prob] \\
\hline FLFP(-1) & -.13651 & .16318 & $-.83653[.415]$ \\
\hline FLFP(-2) & -.82164 & .16381 & $-5.0159[.000]$ \\
\hline GII & -.43538 & .12528 & $-3.4752[.003]$ \\
\hline GII(-1) & .17301 & .13661 & $1.2665[.223]$ \\
\hline
\end{tabular}




\begin{tabular}{|l|c|c|c|}
\hline GII(-2) & -.32602 & .12727 & $-2.5617[.021]$ \\
\hline ENRL & -.41432 & .10772 & $-3.8463[.001]$ \\
\hline ENRL(-1) & -.30040 & .12859 & $-2.3361[.033]$ \\
\hline ENRL(-2) & -.39169 & .10445 & $-3.7502[.002]$ \\
\hline FR & -.10178 & .70613 & $-.14414[.887]$ \\
\hline TOP & .020269 & .023051 & $.87932[.392]$ \\
\hline TOP(-1) & .050533 & .021047 & $2.4009[.029]$ \\
\hline TOP(-2) & .087803 & .021721 & $4.0423[.001]$ \\
\hline FDI & .13290 & .050030 & $2.6564[.017]$ \\
\hline FDI(-1) & .12875 & .043710 & $2.9455[.009]$ \\
\hline UNF & -.23910 & .15606 & $-1.5321[.145]$ \\
\hline UNF(-1) & .38079 & .18953 & $2.0092[.062]$ \\
\hline UNF(-2) & -.37371 & .18107 & $-2.0639[.056]$ \\
\hline CPI & .020189 & .044509 & $.45360[.656]$ \\
\hline CPI(-1) & -.031200 & .036201 & $-.86186[.401]$ \\
\hline CPI(-2) & .13805 & .031302 & $4.4103[.000]$ \\
\hline LOGPCI & 8.5900 & 2.8932 & $2.9690[.009]$ \\
\hline LOGPCI(-1) & -5.5679 & 2.9553 & $-1.8840[.078]$ \\
\hline C & 102.1340 & 28.8431 & $3.5410[.003]$ \\
\hline T & .41340 & .16936 & $2.4410[.027]$ \\
\hline R-Squared & & .99687 & R-Bar-Squared \\
Mean of Dependent Variable & 14.3368 & S.D. of Dependent Variable \\
DW-statistic & & 2.6043 & F-stat. (23, 16) \\
\hline Sor A & \multicolumn{2}{|c|}{$221.7597[0.000]$} \\
\hline
\end{tabular}

Source: Author's estimation

Table: 4 describe the ARDL regression analysis, gender inequality is negative and significant at current and second lag level however, it is insignificant at first lag. There is negative and significant relation between female enrolment ratio and female labour force participation rate with current, first and second lag. Our core variables are foreign direct investment and trade openness which have been taken for measuring the tendency of economic globalization. Result supports that there is positive and significant association between FLFP and trade openness at first and second lag although result is insignificant at current year. Whereas, FDI has also positive link with FLFP at current and first lag. Coefficient of fertility rate has although negative sign but due to insignificant $p$-values there is no relationship between FLFP and fertility rate. Unemployment rate of females shows dramatic results. There is no relation at current lag however positive and significant association at first lag however; negative and significant relation at second lag. Inflation rate has no relation in current and first lag however; there is positive and significant association between inflation rate and FLFP. Per capita income shows positive and significant relation with female labour force participation in current lag while negative and insignificant association at first lag. 
Table: 5

Diagnostic tests

\begin{tabular}{|c|c|c|c|}
\hline Test Statistics & *LM & Jersion & ${ }^{*} \mathbf{F}$ Version \\
\hline A:Serial Correlation & ${ }^{*} \mathrm{CHSQ}(1)$ & $=7.3800[.007]$ & $* \mathrm{~F}(1,15)=3.3936[.085]^{*}$ \\
\hline B:Functional Form & $* \mathrm{CHSQ}(1)$ & $=1.4588[.227]$ & $* \mathrm{~F}(1,15)=.56774[.463]^{*}$ \\
\hline C:Normality & ${ }^{*} \mathrm{CHSQ}(2)$ & $=1.0169[.601]$ & $*$ Not applicable $*$ \\
\hline D:Heteroscedasticity & $* \mathrm{CHSQ}(1)$ & $=1.3094[.252]$ & $* \mathrm{~F}(1,38)=1.2861[.264]^{*}$ \\
\hline
\end{tabular}

Source: Author's estimation

We have applied number of residual diagnostic tests for estimation of consist and unbiased estimation of coefficient. The results of tests prove no evidence of serial correlation functional form error, Heteroscedasticity and normality in the model.

Table: 6

Long run estimation using the ARDL approach

Estimated Model FLFP $=\mathrm{f}(\mathrm{TOP}$, FDI, ENRL,FR, GII, UNF, PCI, CPI)

Lag Structure $(2,2,2,0,2,1,2,2,1)$ selected based on AIC

Dependent variable is FLFP

\begin{tabular}{|l|l|l|l|}
\hline Regressor & Coefficient & Standard Error & T-Ratio[Prob] \\
\hline GII & -.30048 & .071502 & $-4.2025[.001]$ \\
\hline ENRL & -.56503 & .063714 & $-8.8683[.000]$ \\
\hline FR & -.051979 & .36070 & $-.14411[.887]$ \\
\hline TOP & .080997 & .021727 & $3.7279[.002]$ \\
\hline FDI & .13362 & .019621 & $6.8099[.000]$ \\
\hline UNF & -.11849 & .12263 & $-.96622[.348]$ \\
\hline CPI & .064878 & .025652 & $2.5291[.022]$ \\
\hline LOGPCI & 1.5434 & 1.0494 & $1.4707[.161]$ \\
\hline C & 52.1584 & 15.6412 & $3.3347[.004]$ \\
\hline T & .21112 & .088696 & $2.3802[.030]$ \\
\hline
\end{tabular}

Source: Author's estimation

Table 6: represent the long run estimation of the study using ARDL approach to cointegration. The findings shows that gender inequality, foreign direct investment, trade openness and inflation have more impact on raising FLFP in long run at $1 \%$ and $5 \%$ level of significance. In long run, if Pakistan moves towards economic integration with more trade and FDI significantly expand employment opportunities for females in formal and informal sectors both (Mujahid, Shabbir and Shahbaz, 2016; Meyer, 2003). Moreover, in our study, we have found no evidence of any significant relation between FLFP and fertility rate, unemployment rate of female and with per capita income. 
Table: 7

Short run estimates with error correction model

Estimated Model $\quad$ FLFP $=\mathrm{f}($ TOP, FDI, ENRL,FR, GII, UNF, PCI, CPI $)$

Lag structure $(2,2,2,0,2,1,2,2,1$ based on AIC

Dependent variable is dFLFP

\begin{tabular}{|l|c|c|c|}
\hline Regressor & Coefficient & Standard Error & T-Ratio[Prob] \\
\hline dFLFP1 & .82164 & .16381 & $5.0159[.000]$ \\
\hline dGII & -.43538 & .12528 & $-3.4752[.002]$ \\
\hline dGII1 & .32602 & .12727 & $2.5617[.017]$ \\
\hline dENRL & -.41432 & .10772 & $-3.8463[.001]$ \\
\hline dENRL1 & .39169 & .10445 & $3.7502[.001]$ \\
\hline dFR & -.10178 & .70613 & $-.14414[.887]$ \\
\hline dTOP & .020269 & .02305 & $.87932[.388]$ \\
\hline dTOP1 & -.087803 & .021721 & $-4.0423[.001]$ \\
\hline dFDI & .13290 & .05003 & $2.6564[.014]$ \\
\hline dUNF & -.23910 & .15606 & $-1.5321[.139]$ \\
\hline dUNF1 & .37371 & .18107 & $2.0639[.050]$ \\
\hline dCPI & .020189 & .044509 & $.45360[.654]$ \\
\hline dCPI1 & -.13805 & .031302 & $-4.4103[.000]$ \\
\hline dLOGPCI & 8.5900 & 2.8932 & $2.9690[.007]$ \\
\hline dC & 102.1340 & 28.8431 & $3.5410[.002]$ \\
\hline dT & .41340 & .16936 & $2.4410[.023]$ \\
\hline ECM(-1) & -1.9582 & .22630 & $-8.6530[.000]$ \\
\hline Source: Auth's & & & \\
\hline
\end{tabular}

Source: Author's estimation

Table 7 depicts the findings of error correction model (ECM) for short run estimation. For ECM, two criteria should be checked such as the coefficient value of ECM should be negative and significant that proves convergence of variables towards long run from short run paths if any shocks occur. The coefficient value of ECM (-1) is -1.9582 which is negative and highly significant which illustrates the high rate of adjustment from short run equilibrium to long run equilibrium.

\section{Conclusions and Policy Recommendations}

The empirical evidence of long run as well as short run association between economic globalization and female labor force participation in Pakistan has been presented in this study while covering the period of 1974 to 2014. At first step, we have used ADF and PP unit root test in order to check stationary of the data. The results of both test proved that all selected variables are integrated at level and first difference which justifies the application of ARDL method. The finding of the study proves significant and positive association between economic globalization and FLFP in Pakistan. 
More economic integrations through trade and FDI will open new entrance for job opportunities in labor market especially for females. Increase in exports of agriculture and textile product will also increase female labor force participation in those sectors which requires unskilled and cheap labor force. Even cheap labor force is an important factor for FDI although, it requires skilled labor. More export-oriented trade policies and facilitates for skilled labor can be helpful in encouraging female participation. This will further help in reducing gender gap in labor market while providing better opportunities of jobs, education and health. Meanwhile, multinational firms offer employment opportunities for females without discrimination between male and female because they work in competitive environment. It encourage females to find jobs (Kaur, 2018).

Pakistan is a highly populated country whereas females are $48 \%$ of total population and moving toward open economy with more financial and trade liberalization have significant and positive impacts on female labours. The policy makers must focus on narrowing down gender wage gap in formal sectors between male and female in urban and rural region both. The supply side reforms need to improve infrastructure, skill and education in order to creation of new jobs which enables more females to enter in labor market. Whereas; higher investment in human capital can also lead to increase female participation in labour market. Even education of female should be compulsory at least middle level which will improve female ability and skills in the long run and compete with newly skilled based competitive world. The government should ensure safe and profitable business environment that can help in creating jobs opportunities. Furthermore, both demand and supply side factors should also considered in order to raising FLFP through education, training, child care facilities at work place, assurance of legal and institutional polices in order to share burden on domestic duties of females. There is also a need of enhancing safety of females and involvement of private sectors in industries that may bring more opportunities for female to work in formal sector in Pakistan.

\section{References}

Aguayo-Tellez, E. (2012). The Impact of Trade Liberalization Policies and FDI on Gender Inequalities: A Literature Review. World Bank. (c) World Bank. https://openknowledge.worldbank.org/handle/10986/9220 License: CC BY 3.0 IGO.

Aguayo-Tellez, E., Airola, J. \& Juhn, C. (2010). Did Trade Liberalization Help Women? The Case of Mexico in the 1990s, National Bureau of Economic Research, Inc, NBER Working Papers: 16195 Retrieved from: https://www.nber.org/papers/w16195

Ahmed, N. \& Hyder, K. (2006). Gender Inequality and Trade Liberalization: A Case Study of Pakistan. MPRA Paper No. 16252. Retrieved from: https://mpra.ub.uni muenchen.de/16252/1/gender_and_trade_submitted_to_FC.pdf 
Asongu, S. A., Efobi, U. R., Tanankem, B. V. \& Osabuohien, E. S. (2019). Globalisation and Female Economic Participation in Sub-Saharan Africa. Gender Issues, pp.1-29.

Bhalotra, S.R. \& Umaña-Aponte, M. (2012). The Dynamics of Women's Labor Supply in Developing Countries, Institute for the Study of Labor (IZA) Working Paper. Retrieved from file:///C:/Users/as/Downloads/SSRN-id1591706.pdf

Bhalla, S. \& Kaur, R. (2011). Labour Force Participation of Women in India: Some Facts, Some Queries, Asia Research Centre, Working Paper, 40. Retrieved from: http://eprints.lse.ac.uk/38367/1/ARCWP40-BhallaKaur.pdf

Binzel, C. \& Assaad, R. (2011). Egyptian Men Working Abroad: Labour Supply Responses by the Women Left Behind. Labour Economics, vol.18:1, pp.S98-S114.

Çağatay, N. \& Özler, Ş. (1995). Feminization of the Labor Force: The Effects of LongTerm Development and Structural Adjustment. World Development, vol.23:11, pp.1883-1894.

Cagatay, N., Elson, D. \& Grown, C. (1995). Special Issue on Gender, Adjustment and Macroeconomics. World Development, vol.23:11, pp.1825-2017.

Cooray, A., Gaddis, I., \& Wacker, K. M. (2012). Globalization and female labor force participation in developing countries: an empirical (re-) assessment (No. 129). Courant Research Centre: Poverty, Equity and Growth-Discussion Papers. Retrieved from http://www2.vwl.wiso.uni-goettingen.de/courant-papers/CRCPEG_DP_129.pdf

Dolan, C. \& Sorby, K. (2003). Gender and Employment in High-Value Agriculture Industries. Agriculture and Rural Development Working Paper, 7. Retrieved from: http://documents.worldbank.org/curated/en/231481468739343863/pdf/multi0page .pdf

Ejaz, M. (2011). The Determinants of Female Labor . The Force Participation in Pakistan: An Instrumental Variable Approach. CREB Working Paper No. 01-11. Retrieved from: http://www.creb.org.pk/uploads/Working-Paper-No.-01-11-complete.pdf

Elson, D. (1991a). Male Bias in the Development Process: An Overview. In Diane Elson (ed.) Male Bias in the Development Process, Manchester: Manchester University Press 
Elson, D. \& Pearson, R. (1981). Nimble Fingers Make Cheap Workers: An Analysis of Women's Employment in Third World Export Manufacturing. Feminist Review, vol.7:1, pp.87-107.

Esping-Andersen, G., Gallie, D., Hemerijk, A. \& Myers, J. (2002). Why we need a new welfare state. New York: Oxford University Press.

Esping-Andersen, G. (2009). The Incomplete Revolution: Adapting to Women's New Roles. Cambridge: Polity Press.

Fatima, S. T., \& Khan, A. Q. (2019). Globalization and female labor force participation: The role of trading partners. The Journal of International Trade \& Economic Development, 28(3), 365-390.

Fernandes, R. \& Felício. F, De. (2005). The Entry of the Wife into the Labor Force in Response to the Husband's Unemployment: A Study of the Added Worker Effect in Brazilian Metropolitan Areas, Economic Development and Cultural Change, vol.53:4, pp.887-911.

Fontana, M., Joekes, S. P. \& Masika, R. (1998). Global Trade Expansion and Liberalisation: Gender Issues and Impacts. Report No. 42 Brighton: Institute of Development Studies. University of Sussex. Retrieved from: https://s3.amazonaws.com/academia.edu.documents/31489224/Global_trade_exp ansion.pdf?AWSAccessKeyId=AKIAIWOWYYGZ2Y53UL3A\&Expires $=1 \overline{5} 544$ 66631\&Signature=SUTmYuVg1 ADi9mzV3xAIAyhgBgM\%3D\&responsecontentdisposition $=$ inline $\% 3 \mathrm{~B} \% 20$ filename $\% 3$ DGlobal_trade_expansion_and_lib eralisatio.pdf

Gaddis, I. \& Pieters, J. (2012). Trade Liberalization and Female Labor Force Participation: Evidence from Brazil. Discussion Paper, IZA No. 6809 Retrieved from: http://ftp.iza.org/dp6809.pdf

Gaddis, I. \& Pieters, J. (2017). The Gendered Labor Market Impacts of Trade Liberalization Evidence from Brazil. Journal of Human Resources, vol.52:2, pp.457-490.

Galor, O. \& Weil, D. N. (1996). The Gender Gap, Fertility and Growth1. American Economic Review, 3, 86.Greenwood, J. (1984), Non-traded Goods, the Trade Balance and the Balance of Payments, Canadian Journal of Economics, vol.17, pp.806-823. 
Goldin, C. (1990). Understanding the Gender Gap: An Economic History of American Women, New York: Oxford University Press

Gupta, A. (2015). Effect of Trade Liberalization on Gender Inequality: The Case of India. Indian Statistical Institute, Chennai. Retrieved from: file://D:/EffectOfTradeLiberalizationOnGender_preview\%20(3).pdf

Hyder, A. \& Behrman, J. R. (2012). International Trade Openness and Gender Gaps in Pakistani Labor Force Participation Rates Over 57 Years. Journal of the Asia Pacific Economy, vol.17:3, pp.367-382.

Jadotte, E. (2009). International Migration, Remittances and Labour Supply: The Case of the Republic of Haiti (No. 2009.28). Research Paper/UNU-WIDER. Retrieved from: https://www.econstor.eu/dspace/bitstream/10419/45099/1/601794087.pdf

Jaffri, A. A., Sana, M., \& Asjed, R. (2015). Impact of Globalization on Gender Inequality In Labour Market Of Pakistan. Pakistan Economic and Social Review, 1-16

Jokes (1995). Trade-Related Employment for Women in Industry and Service in Developing Countries, United Nation Fourth World Conference on Women, Occasional paper5, URISD, Geneva. Retrieved from: https://cdn.atria.nl/ epublications/1995/Trade_related_employment.pdf

Jokes, S. \& Weston, A. (1994), Women and the New Trade Agenda. New York. UNIFEM.

Kaur, P.(2018). Impact of Globalization on Women. Global Journal of Commerce and Management Perspective, 7(2):41-44

Kuete, S.N.A. \& Voufo, B. T. (2016). How Does Trade Openness affect Women's Job Opportunites and Earning in Cameroon? Retrieved from: https://vi.unctad.org/tag/docs/tagmr/vimrtagcameroon16.pdf

Mammen, K. \& Paxson, C. (2000). Women's Work and Economic Development, The Journal of Economic Perspectives, vol.14:4, pp.141-164.

Masood, F. \& Ullah, S. (2014). Impact of Globalization on Female Labor Force Participation in the SAARC Region, Pakistan Journal of Social Sciences, vol.34:2, pp. 523-533. 
Meyer, L. B. (2003). Economic Globalization and Women's Status in the Labor Market: A Cross-National Investigation of Occupational Sex Segregation and Inequality. The Sociological Quarterly, vol.44:3, pp.351-383.

Moghadam, V.M. (1999). Genderand Globalization: Female Labor and Women's Mobilization, Journal of Word System Research, vol.2, pp.367-388.

Mujahid, N. \& Zafar, N. (2012). Economic Growth-Female Labour Force Participation Nexus: An Empirical Evidence for Pakistan. The Pakistan Development Review, pp.565-585.

Mujahid, N., Shabbir, M. S. \& Shahbaz, M. (2016). Labour Market Conditions-Female Labour Supply Nexus: The Role of Globalization in Pakistan. Global Business Review, vol.17:1, pp.68-87.

Mujahid, N. (2013). Economic Determinants and Female Labor Force Participation: An Empirical Analysis of Pakistan. Developing Country Studies, vol.3:7.

Nissanke, M. \& Thorbecke, E. (2005). The Impact of Globalization on the World's Poor: Transmission Mechanisms. In WIDER Jubilee Conference in Helsinki (pp. 17-8), Retrieved from: http://www.rrojasdatabank.info/widerconf/Nissanke.pdf

Oksak, Y. \& Koyuncu, J. Y. (2017). Does Globalization Affect Female Labor Force Participation: Panel Evidence. Journal of Economics Bibliography, 4(4):381-387.

Palmer, I. (1991), Gender and Population in the Adjustment of African Economies, ILO, Geneva.

Patel, V. (1994). Women and Structural Adjustment in India. Social Scientist, pp.16-34.

Pervaiz, Z., Chani, M. I., Jan, S. A. \& Chaudhary, A. R. (2011). Gender Inequality and Economic Growth: a time series analysis for Pakistan, Middle-East Journal of Scientific Research, vol.10:4, pp.434-439.

Pesaran, M. H. \& Shin, Y. (1999). An Autoregressive Distributed Lag Modelling Approach to Cointegration Analysis, In: Strom, S., Holly, A., Diamond, P. (Eds.), Centennial Volume of Rangar Frisch, Cambridge University Press, Cambridge.

Pesaran, M. H., Y., Shin \& R.J. Smith. (2001). Bounds Testing Approaches to the Analysis of Level Relationships, Journal of Applied Econometrics, vol.16:3, pp.289-326. 
Rees, R. \& Riezman, G. (2012). Globalization, Gender and Growth\|, Review of Income and Wealth, vol.58:1, pp.107-117.

Sauré, P. \& Zoabi H. (2009). Effects of Trade on Female Labor Force Participationl, Working Paper 2009-12, Swiss National Bank, Zurich. Retrieved from: file://D:/SSRN-id1469959.pdf

Schultz, T. P. (1990). Women's Changing Participation in the Labor Force: A World Perspective. Economic Development and Cultural Change, vol.38:3, pp.457- 487.

Seguino, S. (2006). The great equalizer? Globalization Effects on Gender Equality in Latin America and the Caribbean. In A. Shaikh (ed.): Globalization and the Myth of Free Trade (pp. 177-214). London: Routlege.

Shangquan, G. (2000). Economic Globalization: Trends, Risks and Risk Prevention. CDP Background Paper No. 1 ST/ESA/2000/CDP/1

Standing, G. (1989). Global Feminization through Flexible Labor. World Development, $\operatorname{vol} .17(7)$

Tsani, S., Paroussos, L., Fragiadakis, C., Charalambidis, I. \& Capros, P. (2013). Female Labour Force Participation and Economic Growth in the South Mediterranean Countries. Economics Letters, vol.120:2, pp.323-328.

Winters, A. (1991). International Economics, Fourth Edition, Harper Collins Academy and Routledge: London and New York.

Wood, A. (1991). North-South Trade and Female Labor in Manufacturing: An Asymmetry.

Yasmin, F., Amjad, H. \& Ahmad, W. (2013). Impact of Earnings on Female Labor Participation: A Case Study of Tehsil Vehari Pakistan. Middle-East Journal of Scientific Research, vol.18:10, pp.1390-1395

Azeema Begam is Ph.D Research Scholar in the Department of Economics, University of Karachi.

Nooreen Mujahid is an Associate Professor in the Department of Economics, University of Karachi. 